\title{
A TRANSMISSÃO DOS TEXTOS GREGOS E LATINOS (PRINCIPAIS ETAPAS NA TRANSMISSÃO DOS TEXTOS LATINOS)
}

\author{
Marta Barbosa Cortezão ${ }^{1}$
}

RESUMO: Este estudo traz uma abordagem acerca da transmissão dos textos latinos e suas principais etapas históricas, desde a Roma Republicana e Imperial até a época Moderna, enfocando de que forma todas essas etapas lograram contribuir significativamente para os estudos da transmissão de textos, bem como de sua conservação.

PALAVRAS-CHAVE: transmissão clássica, textos latinos, etapas históricas.

RESUMEN: Este estudio hace un abordaje sobre la transmisión de los textos latinos y sus principales etapas históricas desde la Roma Republicana e Imperial hasta la época Moderna, enfocando de qué forma todas estas etapas lograron contribuir significativamente a los estudios de la transmisión de textos, así como la de su conservación.

PALABRAS CLAVE: transmisión clásica, textos latinos, etapas históricas.

\section{INTRODUÇÃO}

O caminho recorrido pelos textos clássicos desde suas origens até a atualidade é evidente que tem sido longo e frequentemente tortuoso, já que são poucas as ocasiões em que a transmissão se dá diretamente das mãos do autor ao público receptor. Por isso, a obra e o mérito pertencem aos estudiosos e eruditos que, incansavelmente, copiaram as obras que, em sua opinião, eram merecedoras de sobreviver ao tempo e ao esquecimento, superando inúmeras vicissitudes até chegarem a ser conhecidas na atualidade. O objetivo deste breve trabalho, dentro do que cabe, é abordar as diferentes etapas históricas que costumam ser consideradas tradicionalmente (época Republicana, época Imperial, Idade Média, Humanismo Renascentista e época Moderna) e as vias de transmissão que os textos latinos tiveram que superar até serem corrigidos e conhecidos e em que medida esse árduo labor no processo de transmissão foi capaz de modificá-los e influenciá-los em relação à sua conservação.

\section{ÉPOCA REPUBLICANA ROMANA}

1 Mestranda em Mundo Clássico e sua Projeção na Cultura Ocidental- UNED/Espanha. E-mail: martabartez@hotmail.com 
Datam do século III a. C. os primeiros registros do surgimento da literatura latina da Roma Republicana através de textos escritos no rolo de papiro, a exemplo do modelo grego. No entanto, já em meados do século II a. C., há constância da livre circulação de livros, tanto de poesia como de teatro e prosa, dentro de uma determinada classe social da Roma Republicana, embora não existam registros sobre o comércio livresco na Roma antes da época de Cícero. Passado um século, na época do apogeu de Cícero e Varrão, o mundo dos livros se tornou sinônimo de instrução no mundo romano erudito. A verdade é que pouco se sabe sobre os meios de transmissão dos textos latinos nos primeiros duzentos anos de existência, tendo em vista as circunstâncias de que o mecanismo para a multiplicação e livre circulação não estava organizado e de que não havia bibliotecas para a conservação dos livros.

A literatura primitiva que chegou até a atualidade foi graças ao trabalho dos primitivos gramáticos romanos, do último século da Roma Republicana, que tiveram a preocupação e o cuidado de coletar e comentar esses textos. Os últimos dias da República foram marcados por algumas mudanças importantes em relação à organização dos meios para a difusão de livros, como a fundação de uma biblioteca pública projetada durante o governo de Júlio César e somente materializada no ano 39 a. C., enquanto que já havia bibliotecas privadas, bem como instituições e processos direcionados para a transmissão da palavra escrita. Segundo se queixa Cícero, o comércio ativo dos livreiros e copistas da época sofre devido à ausência de altos níveis na qualidade de seu trabalho para atender a demanda, com exceção de Ático, cujo nome era sinônimo e garantia de qualidade.

\section{ÉPOCA IMPERIAL ROMANA}

$\mathrm{Na}$ época Imperial Romana, entre os séculos II a. C. e IV d. C., teve lugar um significativo acontecimento para a história do livro e, claro, para a transmissão dos textos clássicos. Através de um processo gradual, surge o códice no lugar do velho rolo de papiro. $\mathrm{O}$ códice, protótipo do livro atual, superava em vantagens ao rolo por ser mais manejável e de um material mais duradouro, também por oferecer o dobro de espaço para o texto, já que poderia ser usado de ambos os lados e, por permitir uma fácil consulta dado que somente havia que remeterse à página exata. Em seus inícios, o códice serviu de instrumento para difundir textos populares e cristãos. O resultado dessa transferência foi um legado intelectual sem precedentes, embora se saiba que houve muitas perdas incalculáveis no transcurso deste processo. 
Os testemunhos que temos deste período sobre a transmissão dos textos são de Cícero e especialmente de Galeno. É uma época em que o comércio do livro floresce e, em consequência, surge uma edição organizada e cuidadosa dos textos. O autor costumava ocupar-se da revisão de suas anotações e da correção dos erros antes da sua publicação final. Numerosas reedições baseadas em edições anteriores de Alexandria foram registradas nesta época Imperial, especialmente, no Renascimento literário do século II, cuja maior parte delas era edições baratas destinadas ao uso popular. Resulta que esses papiros, em comparação com os da época helenística, representam um retrocesso na qualidade do texto, embora sejam de grande relevância para a história da linguagem.

As funções do editor, de acordo com Galeno, eram: conhecer o pensamento e a língua do autor, não fazer correções desnecessárias e consultar várias fontes, manuscritos e escólios, a fim de realizar um minucioso trabalho. Em suma, a transmissão de textos antigos, apesar de ter sofrido os efeitos de sua popularização e as interferências errôneas de eruditos pedantes da época, alcançou sua sobrevivência no decorrer das tradições textuais. O caos político e a ruptura econômica do período imperial romano do século III contribuíram para o declínio intelectual que teve início no século II, o que justifica a ausência de nomes de destaque na literatura romana, à exceção dos escritores apologéticos. Embora a produção desse período não tenha sido importante, é certo que assegurou a continuidade da história da tradição dos textos clássicos na Idade Média.

\section{IDADE MÉDIA}

Os períodos Republicano e Imperial de Roma transcorrem aproximadamente entre os séculos II a. C. e inícios do século V d. C. Após esses períodos, o número de obras registradas vai diminuindo devido aos efeitos sofridos pela conversão ao Cristianismo, época em que o pergaminho adota o valor do livro-símbolo, mais tarde usado para fins particulares, mas com uma profunda transformação em sua estrutura material, uma vez que as práticas livrescas desse período se dedicavam ao uso quase exclusivo do códice.

O códice começou a ganhar repercussão, principalmente, devido à influência do Cristianismo, a partir do século III d. C., ainda que não somente isso, também influenciou em sua implantação a origem social das pessoas promotoras do códice: era patrimônio das classes populares, difundiu a literatura de segunda classe. No entanto, não há dúvida de que recai sobre a Igreja o papel decisivo para a expansão dos códices tanto pelas estatísticas quanto por sua tentativa de diferenciar culturas pagãs e judaicas. Deve-se também fazer referência à influência 
das compilações jurídicas igualmente realizadas nos códices, tornando-se assim o livro no símbolo da divindade e da lei. A partir do século IV d. C., começa um processo uniforme do códice em todos os âmbitos.

As consequências para a transmissão de textos são, em suma, benéficas, uma vez que o códice foi produzido com um material menos dispendioso, mais leve e fácil de manusear e consultar; produz maior rendimento para os estudos escolares e contém maior capacidade de conteúdo textual, podendo ser incluído sob uma única capa em um corpus de textos relacionados entre si ou diferentes trabalhos de um mesmo autor. Talvez a única consequência desfavorável da implementação do códice seja a dificuldade que supôs a transferência dos textos contidos nos pergaminhos para o códice, uma vez que, sem dúvida, se perderam muitos textos que, simplesmente, não foram passados para o novo tipo de livro.

No final do século VIII d. C., com o início do Renascimento Carolíngio, a transmissão de textos vive uma nova etapa. É o momento em que as bibliotecas monásticas e reais começaram a obter os códices antigos, em alguns casos, de autores pagãos e copiá-los através da escrita minúscula carolíngia que foi o veículo de difusão da corte de Carlos Magno e que também foi transmitida até a imprensa moderna sem grandes mudanças. A responsabilidade da rápida propagação desta escrita foi das abadias e mosteiros que, até o final do século IX d. C., já reuniam um número significativo de 6.700 manuscritos. Mas, ao mesmo tempo que um manuscrito original era copiado com a escrita carolíngia, este já não tinha mais valor. Fato que, infelizmente, favoreceu a perda irreparável de inúmeros manuscritos romanos tardios. Embora a Reforma Carolíngia tenha cumprido seu importante papel na transmissão de textos.

Os meios para a difusão do livro estavam especialmente organizados, cuja prática de escrita se caracterizava pela uniformidade; as cópias dos manuscritos de exemplares autorizados tinham uma assinatura que as autenticava. Assim, a grande maioria dos textos latinos atualmente editados se deve aos manuscritos carolíngios, frutos do trabalho dos monges copistas.

No século XII d. C., os cronistas monásticos e as dioceses reuniram os textos antigos dos historiadores romanos e as instituições monásticas recorreram aos manuais de autores como Vitrúvio, Paladio e Vegécio. A sociedade do século XII reflete a opulência e o vigor das novas instituições monárquicas, o que resultou no surgimento de um episcopado erudito.

$\mathrm{Na}$ tardia Idade Média, surgiram as primeiras universidades, cujo objetivo inicial era o ensino dos sacerdotes para defender os interesses da Igreja através da recuperação dos grupos sociais da heresia e da assistência à crescente congregação cristã urbana. No século XIII, as coleções de fragmentos dos textos clássicos mais importantes foram reestruturadas e organizadas em ordem alfabética, com índices temáticos detalhados e abundantemente disseminados. 
Registra-se um crescimento no número de bibliotecas de clérigos e administradores eclesiásticos. Surgem também as assinaturas que eram notas localizadas no final de uma obra ou dos livros de uma obra que se copiavam de manuscrito para manuscrito juntamente com o texto; testemunhos importantes do interesse que se teve pela Literatura Clássica e sua preservação na antiguidade tardia.

\section{HUMANISMO RENASCENTISTA}

Após o Renascimento Carolíngio, três grandes aspectos contribuíram para a transmissão de textos antigos: os manuscritos do século IX d. C. foram transferidos dos centros carolíngios para os novos centros de erudição nos séculos XI e XII; os estudiosos humanistas descobriram textos de autores clássicos que haviam sido ignorados ou de autores cujos textos se havia perdido o rastro de sua existência, como Tibulo, Propércio e Catulo e, finalmente, o surgimento de registros de famílias alternativas ou adicionais de um ou outro texto deixado por copistas das muitas abadias beneditinas ou cistercienses do século XII.

A concepção que o homem do Humanismo tinha do legado clássico o ajudou a enfrentar as mudanças históricas de seu tempo. Este novo olhar sobre o passado clássico do período Humanista Renascentista é uma das coisas que o diferencia da Era Medieval, onde a transmissão dos clássicos dependia em grande parte de sua função utilitária. Os humanistas, em cujas mãos o Renascimento da Antiguidade repousou, se dedicaram à busca de textos latinos esquecidos nas bibliotecas eclesiásticas, abadias e catedrais, durante o transcurso de suas missões diplomáticas.

Esta recuperação dos autores da época antiga mudou substancialmente a forma de escrever e de pensar não só nas disciplinas estritamente literárias, mas no que diz respeito ao direito, à política, à moral e ao estudo dos costumes. Essa cultura clássica pretende ser um valor de integração entre o mundo antigo e o contemporâneo.

O Humanismo, como movimento cultural, permitiu a reconstrução da Antiguidade Clássica com o propósito de promover o conhecimento, embora sua difusão tenha sido desigual. Os estudiosos das obras clássicas tiveram como objetivo principal os textos com lacunas com a intenção de esclarecê-los.

O surgimento da imprensa, em 1454, coincide com o do Humanismo Renascentista da antiguidade, cujo olhar para a transmissão de textos sofreu uma mudança visível em relação ao tratamento obtido na Idade Média. Esta nova invenção tinha por finalidade, em um primeiro momento, multiplicar ao máximo o número de cópias semelhantes ao modelo original do manuscrito e, por conseguinte, o barateamento do produto que passou de um exemplar único a 
múltiplas cópias similares. Esta crescente difusão de livros em toda a Europa mudou gradualmente a maneira dos estudiosos de confrontar-se com os textos e deu lugar à criação de sistemas de pensamentos totalmente novos. Durante este período, as bibliotecas eclesiásticas continuaram seu florescimento até meados do século XVI. No entanto, o surgimento da impressa também gerou algum outro inconveniente para a transmissão de textos, além da negligência, podendo ser que a reprodução em larga escala de novas cópias dos antigos manuscritos tenha provocado o desaparecimento de tais textos.

\section{ÉPOCA MODERNA}

Na época Moderna, do século XVI ao XIX, o surgimento da imprensa e a inclusão das línguas clássicas como disciplinas do currículo acadêmico alteraram substancialmente a natureza da transmissão. A importância dada pelos eruditos modernos ao estudo das línguas clássicas, hebraico, grego e latim permitiu-lhes resolver os problemas textuais através do contato direto com os manuscritos mais antigos. A busca por esses textos antigos se concretizava com o surgimento do ofício de Editor, criado pela imprensa. Os editores, que eram grandes eruditos, aportaram aos estudos da transmissão de textos novas fontes de conhecimento cujas correções e avaliações ainda são úteis para estudiosos modernos.

Com a difusão do livro impresso, a figura do sábio errante que viajava de uma biblioteca para outra em busca do manuscrito exato para solucionar suas dúvidas dá lugar ao erudito sedentário que tinha ao seu redor diversas fontes para confrontá-las, o que contribuiu poderosamente para o nascimento de ciência moderna. A estrutura do livro passa por uma série de mudanças até alcançar a capa moderna (na primeira década do século XVI) com a indicação do título, autor, marca do impressor, lugar e ano. O processo de paginação do livro também ocorreu gradualmente, até princípios do século XVI havia livros sem paginação. Este processo foi importante porque favoreceu a aparência de um terceiro importante elemento que foram os índices alfabéticos ou sistemáticos. O quarto elemento derivou do campo das ciências descritivas, a ilustração, cujo objetivo era a transmissão eficiente da informação.

O início da Filosofia Moderna na Alemanha, em meados do século XIX, põe fim a nosso estudo da transmissão de textos clássicos latinos, abrindo o caminho para a ciência atual, com o aparecimento da Paleografia através da qual se pode conhecer com precisão as datas dos manuscritos conservados, sua origem e as circunstâncias de sua produção.

\section{CONCLUSÃO}


A visão panorâmica acerca da história da transmissão dos textos latinos nos mostrou o cuidado e o estudo com que os processos de conservação da tradição textual foram conduzidos durante esses períodos. Desde os períodos Republicano e Imperial de Roma, houve uma preocupação com a transmissão clássica, mas é durante a Idade Média que a literatura pagã perde certo protagonismo para os textos litúrgicos com a intensificação do processo de conversão ao Cristianismo. É na fase do Humanismo Renascentista que a transmissão de textos atinge seu apogeu para chegar então à era Moderna.

Dentro deste estudo, destaca-se um fato histórico importante que teve seu início na época Imperial Romana e configurou-se na Idade Média: a passagem do rolo ao códice, cujas consequências influenciaram substancialmente na transmissão de textos no que diz respeito aos diferentes formatos, à configuração, ao grau de conservação, às possibilidades de difusão dos manuscritos entre outros aspectos. O estado de conservação da obra se diferenciava dependendo do tipo de material utilizado que poderia ser o papiro enrolado, o códice de papiro, de pergaminho ou, finalmente, o de papel. A verdade é que as transformações do mercado editorial influenciaram no êxito ou na transcendência de um livro, assim como na configuração da literatura, embora não sejam propriamente literários, tem sido assim desde a Antiguidade e é assim na atualidade.

Em geral, todas as etapas históricas contribuíram com avanços significativos para os estudos de transmissão de textos, no entanto, ainda há muito por saber, especialmente, sobre a história da transmissão da Idade Média: quais motivos tiveram os homens da Idade Média para ler e copiar os clássicos e por que razões eles o fizeram. Cada manuscrito pertencente a esta época deve ser tratado como um testemunho real de grande valor, fruto de uma sociedade e de um lugar específico e por uma determinada razão. O medievo é um período dinâmico e pleno de mudanças da história europeia que absorveu todo o conhecimento que pode da Antiguidade para usá-lo em seu favor, de acordo com suas necessidades, por isso deixou tão grande legado para as futuras gerações.

\section{REFERÊNCIAS}

CAVAllo, G., "La alfabetización en Grecia y Roma", Historia de la cultura escrita, A. Castillo Gómez (ed.), Ediciones Trea, Gijón 2001, pp. 69-112.

GUIJARRO GONZÁLEZ, S., "El saber de los claustros: las escuelas monásticas y catedralicias en la Edad Media", Arbor. Ciencia, Pensamiento y Cultura, 184, 731 mayo-junio (2008), PP. 443-455. 
MOROCHO GAYO, "La transmisión de textos y la crítica en la antigüedad" y "La transmisión de textos en Bizancio", Estudios de Crítica textual (1979-1986), Universidad de Murcia, 2003. Pp. 5-32 y 33-61.

REEVE, M. D., "La erudición clásica”, Introducción al humanismo renacentista, J. Kraye (ed.), trad. Esp. Madrid, 1998 (Cambridge University Press, 1996), pp.41-72.

REYNOLDS, L, D. - ILSON N. G., Copistas y filólogos, trad. esp. Madrid 1986, editorial Gredos (Capítulo 1, pp. 11-61).

ROUSE, R.H, en R. Jenkyns (ed.), Capítulo, "La transmisión de textos”, El legado de Roma: una nueva valorización (vers. esp.), Barcelona 1995, pp. 43-61.

RUIZ GARCÍA, E, “Tipología del libro”, Introducción a la Codicología, Madrid 2002, 119141.

Recebido em: 01/09/2018

Aprovado em: 05/11/2018

Publicado em: 10/12/2018 